\title{
Medical Dispute Resolution Between Doctors and Patients in The Legal System in Indonesia
}

\author{
Erna Emlijah ${ }^{1}$, Evita Isretno Israhadi ${ }^{2}$ \\ \{drerna.mata@gmail.com¹,Evita_isretno@borobudur.ac.id²\} \\ Universitas Borobudur, Indonesia ${ }^{1,2}$
}

\begin{abstract}
This paper discusses the resolution of medical disputes, knowing the regulation of health services, and the legal responsibilities of doctors in the event of malpractice according to Indonesian law to know the resolution of medical disputes that can protect both parties in the legal system in Indonesia. This discussion harmonizes the legislation with the real situation in society. The approach used here is a normative legal approach. The approach method uses a statutory approach, a conceptual approach, and a historical approach. There are still shortcomings in the resolution of medical disputes that are taken through litigation and non-litigation channels. Thus, an idea was found through discussion, that a special forum for the resolution of medical disputes was needed.
\end{abstract}

Keywords: medical dispute resolution; health law

\section{Background of Study}

Health is a crucial component of human existence. Satisfaction with welfare and health is a need that must be met by humans. Apart from the essential, additional, and tertiary requirements, well-being satisfaction is the key for people to complete their every practice and ultimately fulfill the three components of human needs. Humans are animals that are resistant to various diseases, therefore medical care must also be supported by good health administration institutions and systems.

The 1945 Constitution of the Republic of Indonesia regulates the freedoms granted to the Indonesian population. One of them is in Article $28 \mathrm{H}$ paragraph (1) which states that every resident has the right to health care. Every Indonesian citizen is guaranteed by law that they have the right to choose a welfare administration that does not pay much attention to their social position. Patient freedom is regulated more fully in Law Number 44 of 2009 concerning Clinics, Law Number 29 of 2004 regarding Clinical Practice, Law Number 36 of 2009 concerning Welfare, and as a purchaser of the provision of health services is regulated by Law Number 81999 concerning Buyer Insurance.

To determine the basis for the claim for errors and negligence of a doctor in carrying out his profession as a health worker, it is quite difficult to determine the size or parameters, despite medical records' existence. Law Number 30 of 1999 concerning Arbitration and Alternative Dispute Resolution has raised a dispute resolution solution outside the court, namely mediation, a problem-solving process, in which an impartial and neutral third party 
cooperates with the disputing parties to seek mutual agreement. The mediator is not authorized to decide disputes, but only assists the parties to resolve issues that are authorized to him, such as in medical malpractice disputes where one party is powerful and tends to be more dominant, the third party plays a crucial role to make equal, equal and equal low in the mediation process.

Based on the above background, several problems need to be further clarified, namely how to regulate health services and the legal responsibilities of medical personnel in the event of malpractice according to Indonesian law and how to resolve medical disputes in the Indonesian legal system.

The purpose of this text is to provide information on health services and the responsibilities of medical personnel in the event of malpractice under Indonesian law and for information on the resolution of medical disputes in the Indonesian legal system. The benefits of writing this manuscript are academic benefits, which are expected to be able to provide understanding to legal academics as a reference for parties who need and are interested in developing it in a further stage.

This type of scriptwriting is normative legal text writing. The writing of normative legal texts is the writing of the legal texts. The writing of the manuscript that is studied in normative legal manuscript writing includes several things such as legal principles, legal systematics, the writing of normative legal manuscripts or library manuscript writing is the writing of manuscripts that examines the study of documents, namely using various secondary data such as legislation, decisions court, legal theory, and can be in the form of the opinion of scholars. The writing of the normative type script uses qualitative analysis, namely by explaining the existing data in words or statements, not with numbers.

The approach method used is the statutory approach (Statue Approach), the conceptual approach (Conceptual Approach), and the historical approach (Historical Approach). The sources and types of legal materials used are primary legal materials, secondary legal materials, and tertiary legal materials. Techniques and tools for collecting legal materials by reviewing and studying various kinds of literature in the form of books, opinions of scholars, and materials obtained from the internet as objects of scriptwriting.

\section{Research Formulation}

The things described in the writing of this legal text raise problems which are summarized in the formulation of the problem, namely:

1. Why do patients often have difficulty in claiming their rights in medical disputes?

2. What is the form and system of dispute resolution that provides tight protection to patients in resolving medical disputes between patients and doctors or dentists and hospitals to enforce patient rights?

\section{Research Method}

\subsection{Type of Research}

The writing of this manuscript uses normative legal script writing. It is focused on secondary data consisting of primary legal materials and secondary legal materials. Primary 
legal materials consist of statutory regulations and other written provisions while secondary legal materials consist of theories, teachings, expert opinions, or sources.

\subsection{Approach}

The writing of this manuscript uses a legal political approach that could answer the problem regarding the form and system of dispute resolution that provides more protection to patients in resolving medical disputes between patients and doctors nor dentists and hospitals to realize patient rights. Satjipto Rahardjo (1983) provides an understanding of legal politics as an activity of choosing and the method to be used to achieve certain social and legal goals in society. The writing of this manuscript uses a legal political approach because it wants to find a law that better protects the interests of patients in medical disputes.

\subsection{Data}

The writing of this manuscript is the writing of a normative legal text that uses secondary data in the form of legal materials consisting of:

\section{a) Primary Legal Material}

1. The 1945 Constitution of the Republic of Indonesia.

2. Civil Code (KUHPerdata)

3. Law of the Republic of Indonesia Number 8 of 1999 concerning Consumer Protection.

4. Law of the Republic of Indonesia Number 36 the Year 2009 concerning Health.

5. Law of the Republic of Indonesia Number 44 of 2009 concerning Hospitals.

6. Law of the Republic of Indonesia Number 29 of 2004 concerning Medical Practice.

7. Law of the Republic of Indonesia Number 30 of 1999 concerning Arbitration and Alternative Dispute Resolution.

8. State Government Regulation of the Republic of Indonesia Number 49 of 2013 concerning the Hospital Supervisory Agency.

9. Regulation of the Minister of Health Number 269/MENKES/PER/III/2008 concerning Medical Records.

10. Decree of the Minister of Health of the Republic of Indonesia Number 129/MenKes/SK/II/2008 concerning Minimum Service Standards for Hospitals.

11. Decree of the Minister of Health of the Republic of Indonesia Number 434/MenKes/SK/X/1983 concerning the Indonesian Medical Code of Ethics (KODERSI)

\section{b) Secondary Legal Material}

Secondary legal materials in the form of legal opinions are obtained from books, papers, articles on Consumer Protection, Hospitals, Dispute Resolution, and Patient Rights, which aims to find out why Patients often experience defeat in fighting for their rights and which dispute resolution is which provides more protection to patients to be used in resolving medical disputes between patients and doctors nor dentists and hospitals to realize patient rights.

\subsection{Data Collection Method}


The data in writing this manuscript is done by:

\subsubsection{Literature Survey}

A literature survey is a collection of data obtained from medical dispute documents, literature books, papers, articles, or results of manuscript writing and applicable laws and regulations and applicable theories related to manuscript writing.

\subsubsection{Interview}

Interviews were conducted to obtain information, data, and knowledge from the relevant sources. Interviews were conducted independently guided by the informants by using a list of questions as a guide for conducting questions and answers to the informants.

\subsection{Analysis}

The analysis used in writing this manuscript uses qualitative analysis of secondary data. The stages of qualitative analysis are carried out with secondary data consisting of primary legal materials and secondary legal materials that are analyzed, both vertically and horizontally. Primary legal materials are analyzed, carried out by synchronizing legal materials that there is no protection for health consumers (patients) in medical disputes. Analysis of several articles contained in the 1945 Constitution of the Republic of Indonesia, Law Number 8 of 1999 concerning Consumer Protection, Law Number 44 of 2009 concerning Hospitals, and Law Number 29 of 2004 concerning Medical Practices. Followed by a legal assessment that aims to find out whether the articles analyzed are still relevant or must be immediately amended in answering the problems in the formulation of the problem. Then it is connected with secondary legal materials in the form of medical dispute case documents, legal literature, and analyzed qualitatively to answer the problem of why in medical disputes patients often experience difficulties in realizing their rights and which forms and dispute resolution systems provide more protection to patients in resolving medical disputes between patients and doctors nor dentists and hospitals to realize patient rights, through a legal political approach. So, that it can draw up a conclusion with a deductive method of thinking.

\section{Discussion}

\subsection{Overview of the Definition of Medical Disputes}

Implicitly Article 66 Paragraph (1) of Law no. 29 of 2004 concerning Medical Practices explains that medical disputes are disputes that occur because the interests of patients are harmed by the actions of doctors or dentists who practice medicine.

The relationship between the patient and the doctor or dentist and the hospital is therapeutic, that is, it does not promise to heal, but is related to the business or process carried out following the Standard Operational Instructions (SOP). In this context, omissions and errors can occur at any time. According to Riati Anggriani, SH, MARS, MHum, negligence can occur in 3 forms, namely malfeasance, misfeasance, and non-feasance. Malfeasance means actions that violate the law or are inappropriate or improper, for example, medical actions without adequate indications. Misfeasance means making the right medical decision, 
but doing it in the wrong way (improper performance), for example, taking a medical action that violates the procedure. Non-feasance means that dispute resolution can be reached in two ways, namely through litigation and non-litigation processes. One way in the non-litigation procedure is through mediation.[1] Litigation is a process where the court makes a decision that binds the disputing parties in a legal process that is at one level. Litigation procedures are carried out at each level of the judiciary, both at the first level, the appeal level, to the cassation level. The two processes, litigation, and mediation are completely different, but both methods are forms of medical dispute resolution. Litigation is widely used for the resolution of medical disputes, but mediation is becoming known to be effective in resolving medical disputes. It should be remembered that the two methods are interdependent, where before carrying out the litigation process, mediation must be carried out first. The litigation process has the most prominent characteristics, namely high costs, long duration, high psychological pressure, as well as the formality and complexity of the litigation procedure.[1];[2]

The contents of the medical record are the rights of the patient as stated in Article 52 Letter (e) of the Law of the Republic of Indonesia Number 29 of 2004 concerning Medical Practice that patients have the right to obtain the contents of the medical record. Furthermore, in Article 12 paragraph (2) paragraph (3) and paragraph (4) of the Regulation of the Minister of Health Number 269/MENKES/PER/III/2008 concerning Medical Records, it is explained that the contents of the medical record are the property of the patient which is made in the form of a summary of the medical record. A summary of the medical record can be provided, recorded, or copied by the patient or authorized person or with the written consent of the patient or patient's family who is entitled to it.

The theoretical basis used in this paper is to use the theory of consumer protection and the theory of procedural justice. These two theoretical foundations become analytical tools to answer the problems raised in the formulation of the problem. The theory of consumer protection will discuss the principles in consumer protection law, while the theory of procedural justice is more concerned with fair procedures for disputing parties in medical disputes.

\subsection{Factors That Cause Patients Often Have Difficulty Realizing Their Rights In Medical Disputes}

Patients are protected and regulated in Indonesian laws and regulations. The theoretical basis for writing this manuscript begins with the theory of consumer protection which in the Consumer Protection Act regulates the rights and obligations of consumers in Indonesia. Consumer rights are regulated in Article 4 of the Law of the Republic of Indonesia Number 8 of 1999 concerning Consumer Protection. Article 4 of the Law of the Republic of Indonesia Number 8 of 1999 concerning Consumer Protection regulates the rights of consumers, one of which is the basis for writing this manuscript, namely Article 4 Letter d of the Law of the Republic of Indonesia Number 8 of 1999 concerning Consumer Protection which reads "the right to have their opinions and complaints heard on the goods nor services used." Article 4 Letter d of the Law of the Republic of Indonesia Number 8 of 1999 concerning Consumer Protection is one of the legal bases used to cover whether or not all consumer rights are fulfilled through the writing of this manuscript. Regarding complaints and opinions that must be heard from a consumer, a consumer also has the right to obtain advocacy, protection, and efforts to resolve consumer protection disputes accurately as written in Article 4 letter e of the Republic of Indonesia Law Number 8 of 1999 regarding Consumer Protection. 
Rules in the laws and regulations that emphasize the existence of patients' rights to the contents of medical records are regulated in Article 52 of the Law of the Republic of Indonesia Number 29 of 2004 concerning Medical Practice, namely that patients in receiving services in medical practice, have the right:

a. obtain a complete explanation of the medical action as referred to in Article 45 paragraph

(3);

b. seek the opinion of another doctor or dentist;

c. get services according to medical needs;

d. refuse medical treatment; and

e. get the contents of the medical record.

Articles that regulate the rights of the patients when receiving harmful health services are not necessarily able to protect patients from medical disputes with doctors and/or dentists and hospitals that provide health services. Thus, medical disputes usually arise and enter the area of civil law due to their private or person-to-person nature.

There are still some injustices experienced by patients even though their rights have been legally protected by the state through existing laws and regulations. As well as the patient's right to have their complaints heard, both the patient and the patient's family feel confused about what to complain about, seeing that the hospital's bureaucracy is very, very strict and with procedures that are quite difficult for patients, and their families to take. Patients have the right to complain about the quality of service received, but the complaint procedure is not explained transparently in the hospital as a health service provider. Then, the rights of patients that are often ignored or denied by hospitals are the rights to the contents of medical records. Patients have the right to the contents of the medical record following the provisions of Article 52 of the Law of the Republic of Indonesia Number 29 of 2004 concerning Medical Practice.

The discussion about patients as consumers of health services will answer the formulation of the problem in writing this manuscript. The first formulation of the problem is about: Why do patients often experience defeat in fighting for their rights? The word "defeat" in the formulation of the problem means that patients tend to always suffer losses both physically, in time, and in costs in fighting for their rights when faced with hospital agencies or professional organizations of health workers such as doctors and/or dentists.

The writing of normative legal texts, in this case, is based on secondary data in the form of primary and secondary legal materials. From the collection of decisions regarding medical disputes and the results of interviews with informants, several questions were answered from these factors, namely that patients who experience medical disputes with doctors and/or dentists and hospitals do not have a background of legal knowledge, so that in the dispute resolution process they are submitted entirely to the requested legal advisor/advocate/lawyer. It should be borne in mind that, not only does ignorance of the law cause patients to always lose in fighting for their rights, but there are also other factors, namely psychological factors where they experience pain and economic factors, namely the high cost for health services received. It greatly affects how the resolution of medical disputes can provide the rights that patients should have.

\subsection{Forms and Dispute Resolution Systems that provide more protection to patients in resolving medical disputes}

There are two ways to settle disputes in the realm of civil law, which are offers for the disputing parties, namely through litigation and non-litigation.[3] The litigation path taken means that the handling of the case is through the judicial process, while non-litigation is the 
settlement of legal problems outside the judicial process. The non-litigation route is generally carried out in civil cases because it is more private in nature.

The provisions of Article 45 Paragraph (2) can be seen that to resolve consumer disputes, there are two options, namely through an institution tasked with resolving disputes between consumers and business actors or through a court within the general court environment. Until now, there has not been found an institution as a place to resolve medical disputes, where the forum is more concerned in the field of law without having the parties to the dispute resolve it in court. A body that is expected to exist will later adopt the concept of non-litigation methods, especially mediation, as has been regulated in the laws and regulations to resolve medical disputes.

The parties to a medical dispute, apart from their legal rights to be fulfilled, also have various factors such as emotional or psychological needs that can also be channeled. It can be fulfilled and is part of the benefits of taking mediation. In mediation, the interests of the parties will be focused, so that not only legal rights but also psychological rights will be channeled through discussions mediated by mediators.[4] Openness is the key to mediation, so it is more suitable to be used to resolve medical disputes. In addition, patients as parties who do not have power in terms of material and education, through mediation can express their wishes directly to other parties, namely doctors and/or dentists and hospitals. The essence of mediation is good faith which is the basis for the dispute resolution process. If the mediation agreement is violated, it can become the basis for a lawsuit to the court, and this is what causes the accumulation of medical dispute cases at every level of the court because it requires a long process. Efforts to resolve medical disputes that provide more protection to patients are through non-litigation channels because it provides space for patients to express their complaints and wishes openly to doctors and/or dentists and hospitals in medical disputes they experience.

Mediation has been carried out so far by the disputing parties in medical disputes is still a classic problem, where the mediator has limited legal and health knowledge. There is a need for a forum that is specifically dedicated to medical disputes so that weaknesses in resolving disputes through court/litigation processes and also some dispute resolution outside court/nonlitigation can be resolved so that patients do not experience difficulties in fighting for their rights and also justice for the medical profession and/or dentists and hospital establishments. The forum consists of members who are truly competent in the fields of law and health to be able to handle medical disputes between patients and doctors and/or dentists and hospitals. This forum was created by considering the condition of patients in medical disputes who are in a weak position, both in terms of health, psychological factors, and economic factors.

The idea was found that the government needs to establish a Medical Dispute Settlement Agency (BPSM) by considering several points that have been obstacles so far. This Medical Dispute Resolution Agency can be under the ministry of health spread across all provinces in Indonesia. BPSM is related to public services for all Indonesian people so that it is within the scope of the executive body. This means that BPSM is a government agency that is independent in dealing with medical disputes so that the scope of the judiciary is helped by the establishment of BPSM, thereby reducing the number of medical disputes in the realm of litigation which is quite time-consuming, energy, and cost-consuming for patients as well as for doctors and/or dentists and hospitals in dispute. It should be remembered that the position of the patient with the doctor and/or dentist as medical personnel and the hospital as a forum for providing health services are balanced and need each other. Patients need doctors to cure diseases and a place for treatment in hospitals and vice versa, patients pay for services that have been provided. 
Important points that must be considered in establishing this Medical Dispute Settlement Agency: Easily accessible; Affordable; It doesn't take long; Confidential; Win-win solution. The difference in the resolution of medical disputes through the Medical Dispute Settlement Agency (BPSM) only lies in the members and mediators who are competent and experts in the legal and medical fields. So that medical disputes that are brought to the Medical Dispute Settlement Agency (BPSM) provide a fair solution for patients as well as doctors and/or dentists and hospitals.

\section{Conclusion and Suggestion}

\subsection{Conclusion}

The writing of the manuscript and the discussion that has been carried out by the author, it can be concluded that:

1. In responding to the formulation of the first problem regarding the difficulty of patients to claim their rights in medical disputes with doctors and/or dentists and hospitals caused by various factors, namely, patient education, the patient's financial-economic situation, restrictions on patients in law and law enforcers to understand the medical world. On the other hand, it is better for the Government to issue regulations regarding the rights of patients, doctors and/or dentists and hospitals, because each of their rights has been regulated through laws and regulations as in Article 4 of the Law of the Republic of Indonesia Number 8 of 1999 concerning Consumer Protection, Article 32 of the Law of the Republic of Indonesia Number 44 of 2009 concerning Hospitals, and Article 52 of the Law of the Republic of Indonesia Number 29 of 2004 concerning Medical Practice.

2. Responding to the formulation of the problem in what form and which dispute resolution system provides more protection to patients, after the preparation of the manuscript and analysis in the discussion, it can be concluded that dispute resolution outside the court/nonlitigation is through creating a special forum, namely the Medical Dispute Settlement Body which is useful for patients' difficulties, fighting for the rights of the profession of doctors and/or dentists as well as for owners of hospital institutions also get equal justice.

\subsection{Suggestion}

Patients should be provided with adequate legal and medical knowledge through an equitable education system. It is something that must be considered and addressed by the Government in improving the quality of education so that the quality of health can be achieved for all Indonesian people as stipulated in Article 28H Paragraph (1) of the 1945 Constitution of the Republic of Indonesia.

It is recommended that health institutions, such as hospitals and legal institutions, provide education on the importance of health law to the public. Hospitals must communicate openly through a transparent management system, providing information/statements and regarding clear information about what medical actions will be chosen and taken by patients. As well as for doctors or dentists to further improve how to communicate with patients, increase friendliness to patients. So, the responsibility for every action that will be taken is increasing, considering that the profession of a doctor or dentist who in serving the community is bound by his oath of office. 
Suggestions for the Government to be able to form a special institution for resolving medical disputes that are in favor of patients should be realized immediately so that patients who have medical disputes with doctors or dentists and hospitals can feel their rights as regulated in the legislation.

\section{References}

[1] Junaidi, Eddy. Mediasi Dalam Penyelesaian Sengketa Medik. Raja Grafindo Persada, Jakarta (2011)

[2] http://www.hukor.depkes.go.id/?art=20

[3] Penyelesaian Sengketa Non Litigasi [non-litigation dispute resolution]. Derived from http://auliaardina.blogspot.com/2010/11

[4] Soemartono, Gatot. Arbitrase dan Mediasi Indonesia. Gramedia, (2006)

[5] Supriadi, Wila Chandrawila. Hukum Kedokteran. $1^{\text {st }}$ Printed. Mandar Maju, Bandung (2001)

[6] http://kebijakankesehatanindonesia.net/sites/default/files/file/2011/M\%20Nasser.pdf

[7] http://www.hukumperseroanterbatas.com/2014/01/15/kewenangan-tugas-dantanggung-jawab-direksi-dalam-perseroan-terbatas/\#sthash.B8HiTLrz.dpuf

[8] http://www.tempo.co/read/news/2013/03/25/058469172/Terjadi-182-KasusMalpraktek 